\title{
Development and application of a bioeconomic efficiency index for beef cattle production in Rio Grande do Sul, Brazil ${ }^{1}$
}

\author{
Vinícius do Nascimento Lampert ${ }^{2,3}$, Júlio Otávio Jardim Barcellos ${ }^{3,4,5}$, Francisco José \\ Kliemann Neto $^{5}$, Leonardo Canali Canellas ${ }^{3,4}$, Matheus Dhein Dill ${ }^{3,5}$, Maria Eugênia \\ Andrighetto Canozzi $i^{3,4}$
}

\footnotetext{
${ }^{1}$ Financed by Fundação de Apoio ao Desenvolvimento do Ensino, Ciência e Tecnologia do Estado de Mato Grosso do Sul (FUNDECT).

${ }^{2}$ Curso de Agronomia - Universidade Estadual de Mato Grosso do Sul (UEMS) - Unidade Universitária de Cassilândia - MS.

${ }^{3}$ Núcleo de Estudos em Sistemas de Produção de Bovinos de Corte e Cadeia Produtiva (NESPRO) - UFRGS.

${ }^{4}$ Programa de Pós-Graduação em Zootecnia-UFRGS.

5 Programa de Pós-Graduação em Agronegócio - UFRGS.
}

\begin{abstract}
An index was developed to estimate the bioeconomic efficiency of production systems, identifying alternative scenarios that could improve their efficiency, and building isoefficiency relations in beef cattle production systems in Rio Grande do Sul. The concept of return on investment was used to develop the indicator. Scenarios regarded as efficient showed values higher than 3. The bioeconomic efficiency index for beef cattle production in the theoretical reference scenario was considered inefficient. At least four modifications in the variables method made it a bioeconomically efficient activity. These circumstances were studied using sensitivity analyses, with theoretical changes in the scenarios by changing variables two by two, while the others were kept constant. In Rio Grande do Sul, alternatives that make the activity efficient were identified by changing productivity, production cost, land price and product price. Isoefficiency relationships were identified in other scenarios. The application of this indicator in other agricultural activities, as well as the design of bioefficiency studies including both environmental and social welfare characteristics are recommended.
\end{abstract}

Key Words: capital, cattle farming, productivity

\section{Introduction}

Due to the increase in land prices (ANUALPEC, 2010) and in the global demand for food (FAO, 2011; Foresight, 2011) and for addressing environmental issues (Carvalho et al., 2010), Brazilian beef production has been compelled to improve its productivity (Costa, 2010). The different combinations between land price, product price, production cost, productivity and capital invested in animals determine the bioeconomic efficiency of a system.

The expansion of agriculture has increased land price (ANUALPEC, 2010; Dias-Filho, 2010) as well as investments in agriculture by foreign and Brazilian investors (Gasques et al., 2008). Despite being usually among the lowest in the world (Ferraz \& Felício, 2010), meat production costs in Brazil have increased (Carvalho et al., 2008), contributing to the low profitability as compared with other activities.

Brazil is still one of the few countries with potential to significantly increase its agricultural area and productivity (Gasques et al., 2008), but this prospective expansion requires the identification of relationships that allow the analysis of scenarios where the bioeconomic efficiency of agricultural activity is increased or maintained. Characterizing different components of the production system, understanding their interactions and developing synthesis methods that allow quantifying and following up the improvement process of the efficiency of the system as a whole still poses a challenge to research (Abreu \& Lopes, 2005).

Production costs change according to region (ANUALPEC, 2010), as well as productivity and profitability among systems and within a same system in different years, as a consequence of weather, market and management conditions. Due to this variability and to the lack of accurate official information, the present study was based on a theoretical reference scenario. A method was developed and applied to the state of Rio Grande do Sul, which presents different production systems with different combinations of production activities (SEBRAE; SENAR; FARSUL, 2005).

The objectives of the present study were to develop an index to estimate the bioeconomic efficiency and to identify alternative scenarios to increase efficiency, thereby building isoefficient relationships between beef cattle production systems in the state of Rio Grande do Sul. 


\section{Materials and Methods}

Data from the theoretical reference scenario were obtained from information of the Brazilian Institute of Geography and Statistics (Instituto Brasileiro de Geografia e Estatística-IBGE, 2006), FNP Consulting (ANUALPEC, 2010) and beef cattle production diagnosis of the state of Rio Grande do Sul (SEBRAE; SENAR; FARSUL, 2005), which was carried out by the Universidade Federal do Rio Grande do Sul (Table 1).

Producing on cheap land, with low production costs and low production per hectare, and producing on expensive land, with high production costs and high production per hectare may be inefficient. Bioeconomic efficiency does not depend exclusively on productivity, price obtained for the products or land prices. I. It is possible to be efficient with low or high values for any of the variables, as long as there is compensation by the other variables. Efficiency is determined the combination of these values. The bioeconomic efficiency index proposed in this study allows evaluating this combination using isoefficiency relationships.

An isoefficiency relationship is a set of different values that do not change the bioeconomic efficiency index. This index may increase or decrease as a function of direct or indirect relationships (trade-offs) between the variables considered in the method, which are classified as input variables (revenues) and output variables (expenses) (Figure 1).

When variables are analyzed in pairs, there are ten possible combinations between the index values. The bioeconomic efficiency index may remain unchanged when two variables change their value in the same direction (direct relationships) or in opposite directions (indirect

Table 1 - Theoretical reference scenario of beef cattle production in calving-to-fattening systems in Rio Grande do Sul, Brazil

\begin{tabular}{lcc}
\hline Parameter & Unit & Value \\
\hline Exploited area & Hectares & $1,000.00$ \\
Land price & $\mathrm{R} \$$ ha $^{-1}$ & $3,128.61$ \\
Product price & $\mathrm{R} \$$ live kg-1 $^{-1}$ & 2.74 \\
Production costs & $\mathrm{R} \$$ ha $^{-1}$ & 100.00 \\
Stocking density & $\mathrm{AU} \mathrm{ha}$ & 0.70 \\
Production per hectare & $\mathrm{kg} \mathrm{LW} \mathrm{ha}^{-1}$ & 102.60 \\
Output rate & $\%$ & 21.00 \\
Fixed assets in animals & $\mathrm{R} \$ \mathrm{AU}^{-1}$ & 616.50 \\
Minimal attractiveness rate p.a. & $\%$ & 6.00
\end{tabular}

Source: exploited area (calculation performed by the authors based on IBGE data, 2006).

land price - pastures (Gasques et al., 2008), product price, production cost, and fixed assets (calculations based on ANUALPEC data, 2010); stocking rate, production per hectare and output rate (calculations based on SEBRAE/SENAR/ FARSUL data, 2005); minimal attractiveness rate (author estimation that the capital opportunity cost is equal to revenues generated by savings account investments).

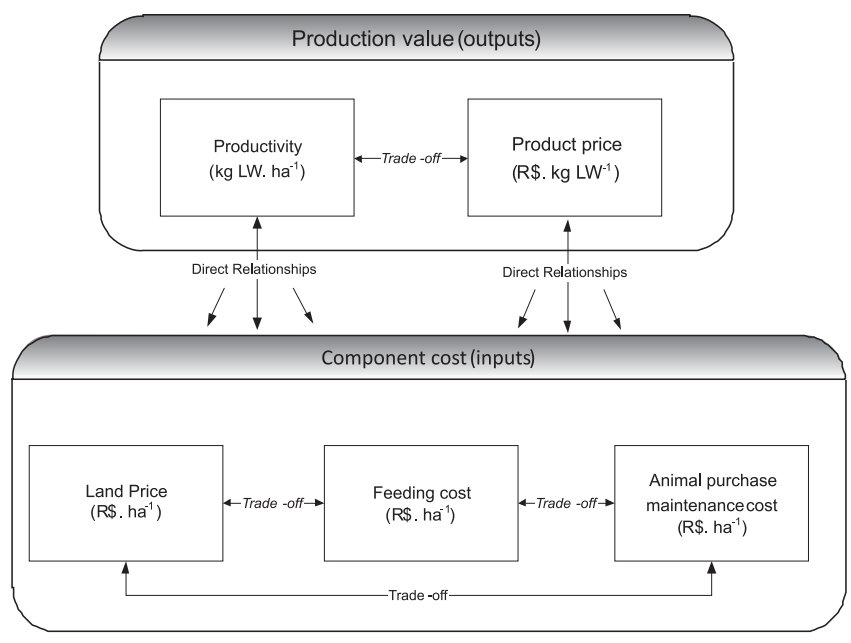

Figure 1 - Description of the direct and indirect relationships between variables determining the bioeconomic efficiency of beef cattle production systems.

relationships). Systems are considered bioeconomically isoefficient when presenting equal bioeconomic efficiency index values.

The method proposes to individually estimate the bioeconomic efficiency of the components soil, plant, and animal in calving-to-fattening beef cattle production systems and to include these components through their weighted efficiency, using the weights of the capital involved in each component as weighting factors. The efficiency is measured as the result of the division between production value and production cost.

The individual efficiency of the components soil, plant, and animal is calculated as follows:

a) Efficiency of the component soil (SE) = relationship between production value and annual opportunity cost of the capital invested in land and facilities.

$S E=\frac{(A P \times P P)}{S C}$,

where: $\mathrm{AP}=$ annual animal production in $\mathrm{kg}$ of live weight $(\mathrm{kg} \mathrm{LW}) ; \mathrm{PP}=$ average product price $\left(\mathrm{R} \$ \mathrm{~kg} \mathrm{LW}^{-1}\right)$; $\mathrm{SC}=$ annual opportunity cost of the component soil (R\$).

The annual opportunity cost of the soil is obtained by the multiplication of the market purchase value of the exploited area by minimum acceptable rate of return. This rate was considered as $6 \%$ per year, in relation to the opportunity cost and venture risk as compared with alternative investment in savings account.

b) Efficiency of the component plant (PE) = relationship between production value and annual cost for the establishment of pastures and the production and supply of feed and supplements to the cattle. 
$P E=\frac{(A P \times P P)}{P C}$,

where: $\mathrm{AP}=$ annual animal production $(\mathrm{kg} \mathrm{LW})$; $\mathrm{PP}=$ average product price $\left(\mathrm{R} \$ \mathrm{~kg} \mathrm{LW}^{-1}\right) ; \mathrm{PC}=$ annul capital invested in the component plant ( $\mathrm{R} \$$ ).

In order to make calculations easier, all production cost expenses, such as labor, veterinary products, fence maintenance, betterments, and equipment were included in this component. This component represent all production costs required to provide adequate conditions for cattle rearing, except for lease or land opportunity costs and cattle purchase or maintenance costs, which were taken into account in other components.

The capital invested in the component plant is relative to the costs of feeding and medication. This is a broad expression to designate this component, as feeding is the expense with the highest cost in all animal production systems, including beef cattle (Archer et al., 1999).

c) Efficiency of the component animal (AE) = relationship between production value and the capital value invested in cattle.

$A E=\frac{(A P \times P P)}{A C}$,

where: $\mathrm{AP}=$ annual animal production $(\mathrm{kg} \mathrm{LW})$; $\mathrm{PP}=$ average product price ( $\mathrm{R} \$ / \mathrm{kg}$ live weight); $\mathrm{AC}=$ capital invested in the component animal (R\$).

The capital invested in the component animal is divided in two types: capital for the purchase of cattle and fixed capital cost. The first refers to animals that are purchased to replace those that were sold during the current year, whereas the latter refers to animals that remain in the herd. AC represents the sum of the values paid to purchase cattle and the opportunity cost of the animals that remained in the herd for the following year.

The bioeconomic efficiency index measures the quotient between the production value and the annual capital relative to the three components. The weighting factors of the index are the costs of the components.

$B E I=\frac{(S E \times S C)+(P E \times P C)+(A E \times A C)}{S C+P C+A C}$

The beef cattle production bioeconomic efficiency index is mathematically simplified, resulting in an equivalent formula:

$B E I=3 \times \frac{A P \times P P}{S C+P C+A C}$

The bioeconomic efficiency index divided by three has a similar concept of those of return on invested capital or of benefit/cost, where individual efficiency measures can be used to evaluate the efficiency sensitivity of each component; however, in the present study, only isoefficiency relationships of bioeconomic efficiency index were analyzed.

A bioeconomic efficiency index of a beef cattle enterprise equal to 3 means that the return obtained with the products is equal to the capital invested in the production components, that is, the quotient between product value and the sum of components cost is equal to 1 .

The interpretation of the results is as follows: when the bioeconomic efficiency index is higher or equal to 3 , the activity is efficient; when it is lower than 3 , the activity is inefficient. The unit of the index is non-dimensional. The bioeconomic efficiency index can become equal to 3 by changing the value of the minimum acceptable rate of return. The limit rate that separates bioeconomic efficiency from inefficiency, as measure by bioeconomic efficiency index is called bioeconomic efficiency rate. Investing in beef cattle production is equivalent to the alternative capital investments when their annual return rates are equal to bioeconomic efficiency rate. Despite being similar, the concept is not the same as Internal Rate of Return (IRR), as it does not require several values in time in order to be calculated.

The present method can also be applied to other agricultural activities, which requires defining which components will be evaluated and assigning their economic values. PV is the generalization of the production value obtained in beef cattle production by multiplying PP by AP. The general generalized formula obtained from the previous formula is:

$B E I=N \times \frac{\sum_{i=1}^{k} P V_{k}}{\sum_{i=1}^{N} C_{N}}$,

where: $\mathrm{N}=$ is the number of components (inputs); $\mathrm{K}=$ amount of products of the activity; $\mathrm{PV}_{\mathrm{k}}$ is the value of production output $_{k}(\mathrm{R} \$) ; \mathrm{C}_{\mathrm{N}}$ is the production cost of component ${ }_{N}(R \$)$. The interpretation of the results is that a bioeconomic efficiency index higher or equal to $\mathrm{N}$ is efficient, whereas bioeconomic efficiency index lower than $\mathrm{N}$ is inefficient. This index allows comparing input efficiencies within a farm.

Theoretically, systems can have the same efficiency with different productivity or different efficiencies with the same productivity. This depends on the different combinations between input and output variables, which may determine equivalent efficiencies between systems.

In order to understand these relationships in beef cattle production in the state of Rio Grande do Sul, some variables were submitted to theoretical changes. The variables used were land price, product price, productivity and production 
costs, except for animal fixed capital. In the present analysis, two variables were changed each time, while the others remained constant, totaling six isoefficiency relationships (Table 2).

These scenarios describe the application of the proposed method, using the main variables that influence bioeconomic efficiency. The method may also be applied to create and evaluate other combinations with data obtained in different regions. In addition, it may be used to compare the efficiency between systems or within the same system between different years.

\section{Results and Discussion}

The bioeconomic efficiency index of beef cattle production of the theoretical reference scenario was inefficient, with a value of 2.22, and individual efficiencies of the soil, plant and animal of 1.50, 2.81 and 3.06, respectively. However, in four of the tested scenarios, that activity was efficient (Table 3 ) as a function of changes in the index variables. Scenario 1 considered an increase in productivity; scenario 2, an increase in product price; in scenario 3 , a reduction in production cost; and scenario 4 , a reduction in land price.

In order to obtain favorable efficiency (bioeconomic efficiency index equal to three) while maintaining the other variables of the theoretical scenario constant, in scenario 1 , the production of live weight per hectare should be $138.5 \mathrm{~kg}$ instead of $102.6 \mathrm{~kg}$ (35.1\% increase), while using the same inputs with the same costs. In scenario 2, product price should be $\mathrm{R} \$ 4.16$ instead of $\mathrm{R} \$ 2.74$ (51.8\% increase). In scenario 3 , production cost should be $\mathrm{R} \$ 2.00$ instead of
$\mathrm{R} \$ 100.00$ per hectare (98.0\% reduction). In scenario 4, land price should be $\mathrm{R} \$ 1.489 .00$ instead of $\mathrm{R} \$ 3.128 .61$ per hectare (52.4\% reduction) to allow similar profitability as a capital return rate of $6 \%$ per year.

When considering that capital does not have a value in time, bioeconomic efficiency index is 4.85 , that is, beef cattle production is bioeconomically efficient when the required interest rate is zero. The requirement of high minimum acceptable rate of return values obviously makes that activity inefficient, whereas low values make it efficient. The bioeconomic efficiency rate is 3.13\% per year (which makes bioeconomic efficiency index equal to three). This value is somewhat higher than that published in ANUALPEC (2010), which states that beef cattle profitability in the region with the highest concentration of beef cattle in the state of Rio Grande do Sul is 1.6\% per year for scales with 500 animal units (AU) and 3.1\% per year for scales of 5,000 AU. In the scale used in the present study (1,200 AU), obtained by interpolation, the profitability of the region is $1.83 \%$ per year.

Isoefficiency relationships were created by changing two variables (Table 3) at each time. These relationships can be used as an answer to some questions, particularly when companies intend to remain in regions subject to efficiency losses caused by increases in land price or production costs. Isoefficiency relationships raise the following questions:

I) Under which circumstances do systems present similar efficiency: with lower production costs on expensive land or higher costs on cheap land?

The loss of beef cattle production profitability, along with external pressures, such as the economic attractiveness

Table 2 - Bioeconomic isoefficiency relationships evaluated for beef cattle production in the state of Rio Grande do Sul

\begin{tabular}{cccc}
\hline Relationships & Variables & \\
\hline 1 & Land price & Production cost & Product price \\
2 & Land price & Productivity & Productivity \\
3 & Productivity & Product price & Production cost \\
4 & Production cost & Product price & Price \\
5 & Production cost & Productivity & Land price \\
6 & Land price & Product price & Land price \\
\hline
\end{tabular}

Table 3 - Alternative scenarios of bioeconomic efficiency of beef cattle production in the state of Rio Grande do Sul

\begin{tabular}{lcccccc}
\hline Variable & Unit & Current situation & Scenario 1 & Scenario 2 & Scenario 3 & Scenario 4 \\
\hline Productivity & $\mathrm{kg} \mathrm{LW} \mathrm{ha}^{-1}$ & 102.6 & 138.5 & 102.6 & 102.6 & 102.6 \\
Product price & $\mathrm{R} \$ \mathrm{~kg} \mathrm{LW}^{-1}$ & 2.74 & 2.74 & 4.16 & 2.74 & 2.74 \\
Production cost & $\mathrm{R} \$ \mathrm{ha}^{-1}$ & 100.00 & 100.00 & 100.00 & 2.00 & 100.00 \\
Land price & $\mathrm{R} \$ \mathrm{ha}^{-1}$ & 3.128 .61 & 3.128 .61 & 3.128 .61 & 3.128 .61 & 1.489 \\
Variation & $\%$ & - & 35.1 & 51.8 & 98.0 & 52.4 \\
BEI & & 2.22 & 3.00 & 3.00 & 3.00 & 3.00 \\
\hline
\end{tabular}

BEI - bioeconomic efficiency index. 
of soybeans, corn, and sugarcane, influence farmers to reduce or even eliminate areas used for cattle production. This phenomenon displaces beef cattle production to marginal regions, where land opportunity costs are lower (Carvalho et al., 2008).

As land prices increase, bioeconomic efficiency becomes equivalent, provided production costs are reduced by $\mathrm{R} \$ 60.00$ per hectare for each $\mathrm{R} \$ 1,000.00$ increase in land price (Figure 2). In the isoefficiency relationships, the other variables remain constant.

II) Under which circumstances do systems present similar efficiency: producing less on cheaper land or more on more expensive land?

Due to the trend of migration of beef cattle production to the Brazilian agricultural frontiers, such as the North, where land is cheaper, beef cattle production technology requirements may be reduced in those regions (Homma, 1999; Barros et al. 2002; Dias-Filho, 2010). In general, the economic pressure to increase production per hectare on cheaper land is lower, and therefore, the current trends are low production on cheap land or high production on expensive land.

According to Dias-Filho (2010), one of the consequences of increases in land cost is either abandoning beef cattle production or making it more intensive. When facing higher land opportunity costs, the economic results of beef cattle production may increase by improving performance indexes (Carvalho et al., 2008) or increasing pasture allowance capacity. Therefore, a possible alternative to continue to produce in areas with high land prices is to intensify production. The same bioeconomic efficiency can be achieved if production is increased in $16.2 \mathrm{~kg}$ live weight per hectare for each $\mathrm{R} \$ 1,000$ of land price per hectare (Figure 3). Other analyses may be performed, considering changes in the three variables, such as the joint effect of increases in land price, production costs and productivity.

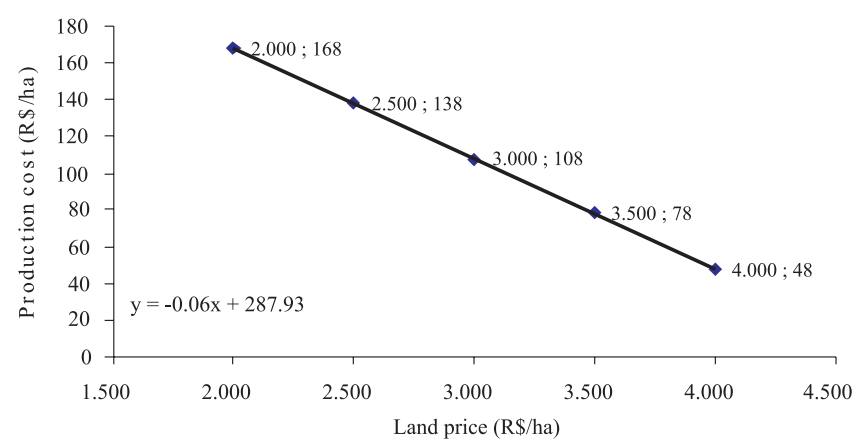

Figure 2 - Trade-off isoefficiency relationships between land price and production cost, maintaining production per hectare and product price constant.

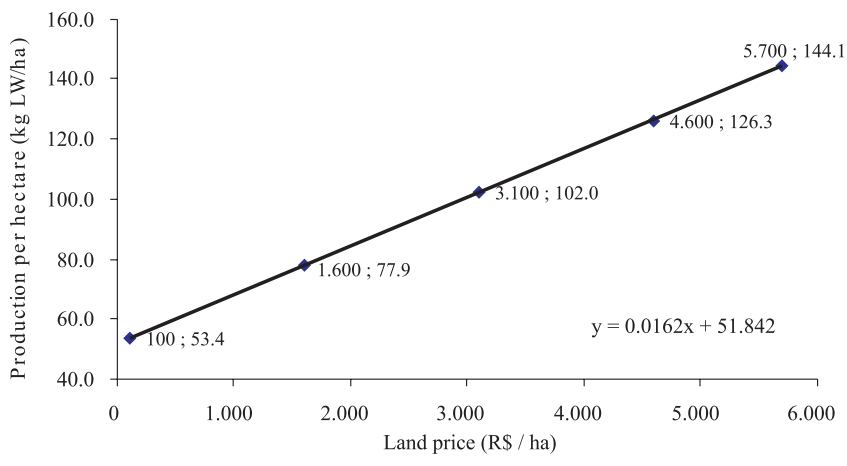

Figure 3 - Isoefficiency curve of the direct relationship between land price and production per hectare, maintaining product price and production cost constant.

III) Under which circumstances do systems present similar efficiency: producing less with high price or more with low prices?

Due to the price seasonality of the beef cattle production (Sachs \& Pinatti, 2007), the risk of the losses caused by price reduction may be lower when productivity is higher if there are cash flow benefits. It can be observed that the capacity of maintaining bioeconomic efficiency increases with productivity. For each $10-\mathrm{kg}$ increase in the production of live weight per hectare, efficiency remains the same, in spite of the $\mathrm{R} \$ 0.50$ reduction in product price per $\mathrm{kg}$ live weight. In this isoefficiency relationship, efficiency is not compromised when price is lower, but productivity is higher (Figure 4).

IV) Under which circumstances do systems present similar efficiency: producing the same amount with higher or lower costs and prices?

The finishing index of ESALQ/BM \& FBovespa (São Paulo, cash - CDI) accumulated a 47.2\% level, increasing from R \$ 79.56 to R 117.18 between May and November of 2010, in actual values (values deflated by the IGP-DI)

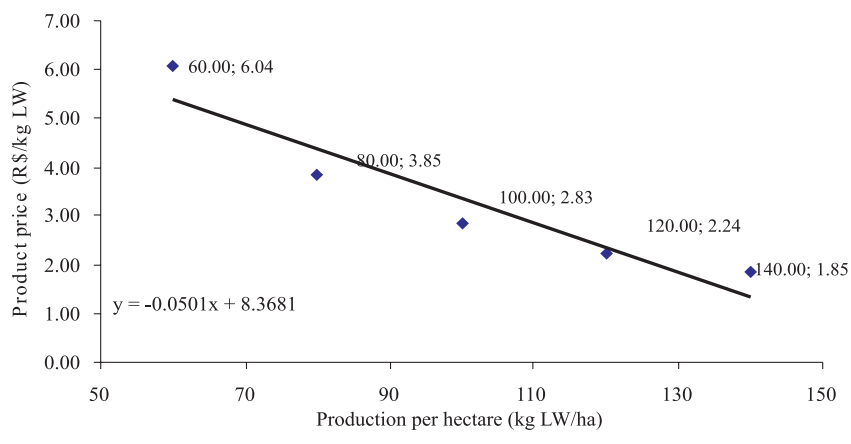

Figure 4 - Isoefficiency curve of the direct relationship between production per hectare and product price, maintaining land price and production cost constant. 
(CEPEA, 2010). This price increase stimulates production intensification, and this also applies when the opposite occurs.

When the price per $\mathrm{kg}$ live weight is increased or reduced in $\mathrm{R} \$ 0.50$, the bioeconomic efficiency remains unchanged if the production cost fluctuates in the same direction at a value of R $\$ 52.55$ per hectare (Figure 5).

V) Under which circumstances do systems present similar efficiency: producing less at lower costs or more with higher costs?

Under an economic perspective, it is possible to increase production when the increase in revenues is higher than the increase in costs. Under these conditions, in order to maintain the same bioeconomic efficiency, an increase of R\$ 50.00 in production costs per hectare demands an increase of $13.5 \mathrm{~kg}$ live weight per hectare in beef cattle productivity (Figure 6). According to Carvalho et al. (2010), in some regions of Brazil, if investments are made to increase

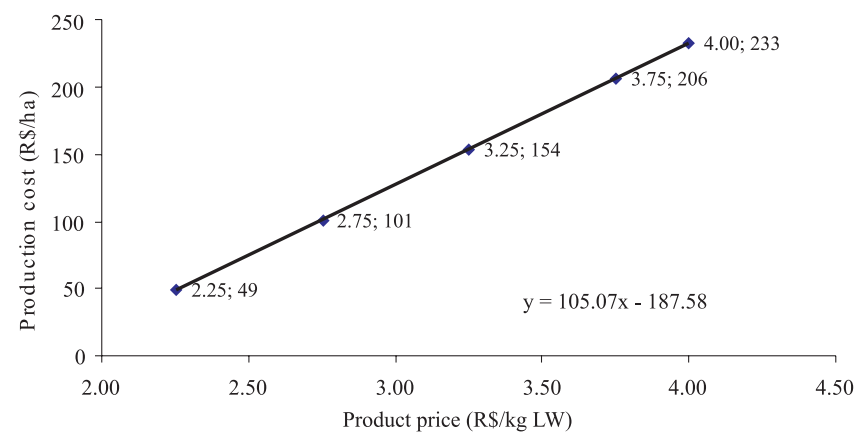

Figure 5 - Isoefficiency curve of the direct relationship between product price and production cost, maintaining productivity and land price constant.

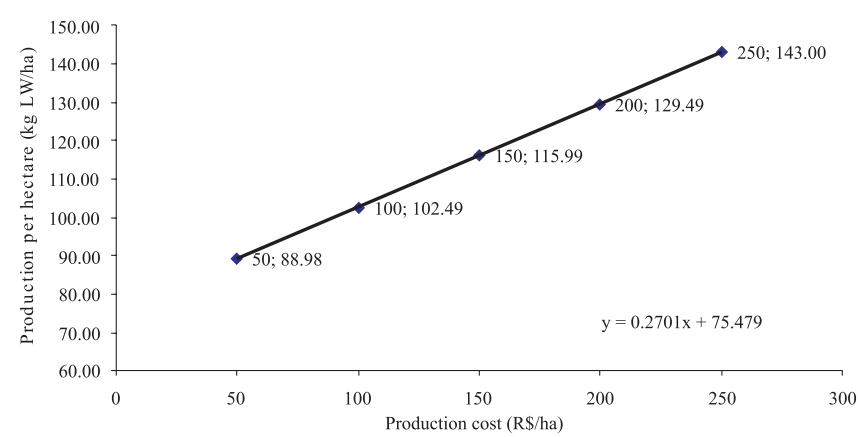

Figure 6 - Isoefficiency curve of the direct relationship between production cost and productivity, maintaining product price and land price constant. pasture allowance capacity, production may triple, quadruplicating profitability.

VI) Under which circumstances do systems present similar efficiency: in cheap land with low product price or in expensive land with higher product price?

In regions with cheaper land prices, the bioeconomic performance can be maintained if the price per kg live weight sold is $\mathrm{R} \$ 0.60$ lower for each $\mathrm{R} \$ 1.000 .00$ higher price per hectare (Figure 7). In the state of Rio Grande do Sul, this difference is relevant in beef cattle production regions because, according to ANULPEC (2010), the price of the most expensive land is about 5 times higher relative to the cheapest land.

The map of isoefficiency summarized relationships for calving-to-fattening beef cattle production systems in the state of Rio Grande do Sul (Figure 8).

No studies doing this type of analyses were found in literature. However, there are more than 40 indexes of the

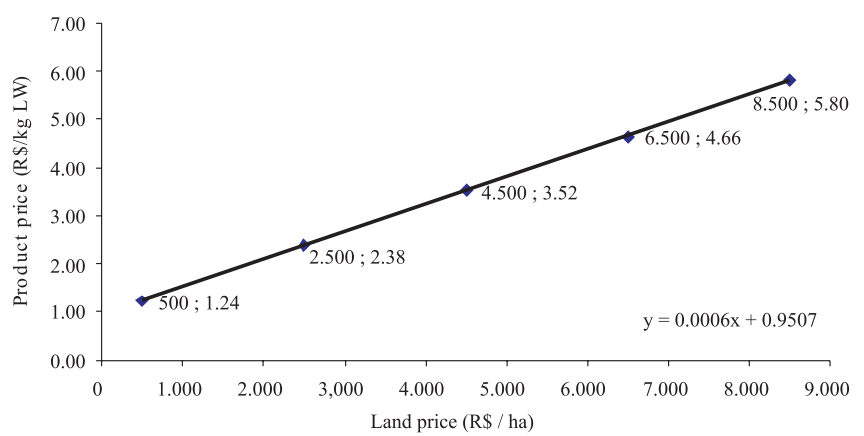

Figure 7 - Isoefficiency curve of the direct relationship between land price and product price, maintaining production per hectare and production cost constant.

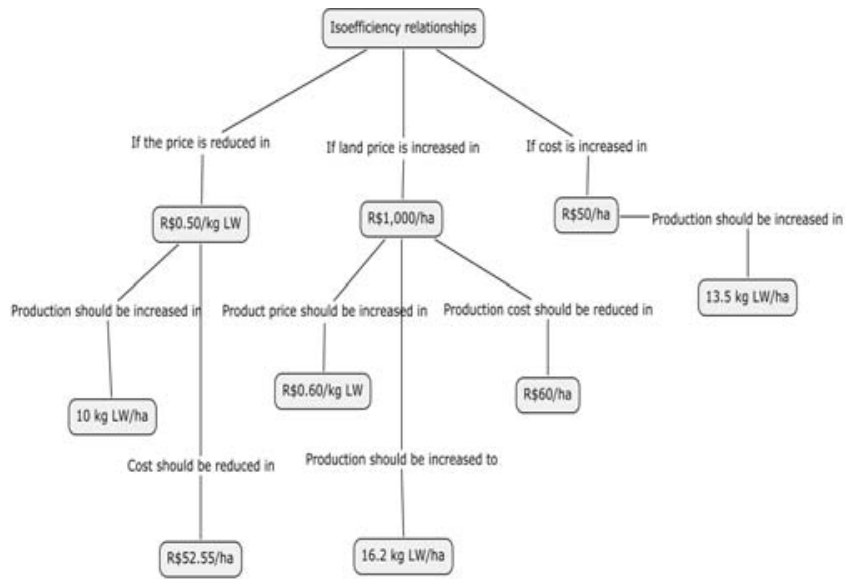

Figure 8 - Map of the isoefficiency relationships for calving-tofattening beef cattle production systems in the state of Rio Grande do Sul. 
efficiency of feed use (Almeida, 2005), mostly correlating a production input, such as hectare or kg of feed consumption, with $\mathrm{kg}$ of live weight produced. In the study of Santos et al. (2008), for instance, the expression. "bioeconomic efficiency" was used to evaluate different nitrogen doses and their effects on gross profit per hectare and on benefit to cost ratio. In a study with dairy cattle, Rennó et al. (2008) evaluated the bioeconomic efficiency of the relationship between feeding cost and gross profit, whereas Barros et al. (2005), in a study with sheep, analyzed the bioeconomic efficiency of gross margins per kg of lamb produced.

Another method used to evaluate the efficiency of systems is the Data Envelopment Analysis. The first studies using this methodology in Brazil (Somwaru \& Valdes, 2004; Abreu et al., 2006; Abreu et al., 2008) evaluated the efficiency of different beef cattle production systems. Despite the potential use of that method for beef cattle production systems, it does not apply to the objectives of the present study. While the data envelopment analysis uses efficient farms as a benchmark for inefficient farms, the present study evaluates the absolute bioeconomic relationships between input values and output values within a company instead of the productive relationships among different production units. Efficiency is measured per se, as it considers productive and economic aspects of the systems, aiming at obtaining the highest return on invested capital.

The bioeconomic efficiency index can be adapted to other activities, and the inclusion of concepts of economic valuation of environmental assets and services, with a focus on social wellbeing is suggested. In order to add components relative to social or environmental aspects, the methods of environmental economic valuation proposed by Motta (1998), Nogueira et al. (2000) and Maia et al. (2004) are associated to the method proposed here.

\section{Conclusions}

Beef cattle production in calving-to-fattening systems in the state of Rio Grande do Sul is inefficient in the evaluated theoretical scenario. Alternative scenarios that increase the bioeconomic efficiency of this activity through isoefficiency relationships between the variables land price, production cost, production per hectare and product price were identified. Bioeconomic efficiency improvement depends on the managerial ability to make changes within the limits of the variables of the isoefficiency maps, considering local production and market characteristics. Therefore, the method can be potentially used to aid strategic decisions, such as land acquisition and production intensification. It can also be applied to other agricultural activities.

\section{Acknowledgements}

The authors are thankful to Fundação de Apoio ao Desenvolvimento do Ensino, Ciência e Tecnologia do Estado de Mato Grosso do Sul (FUNDECT) for the fellowship granted to the Ph.D. student Vinícius do Nascimento Lampert, and to Conselho Nacional de Desenvolvimento Científico e Tecnológico (CNPq), for the Research Productivity grant given to Professor Júlio Otávio Jardim Barcellos.

\section{References}

ABREU, U.G.P.; LOPES, P.S. Análise de sistemas de produção animal - Bases conceituais. Corumbá: Embrapa Pantanal, 2005. 29p.

ABREU, U.G.P.; LOPES, P.S.; BATISTA, A.J.M.S. et al. Avaliação da introdução de tecnologias no sistema de produção de gado de corte no Pantanal: análise de eficiência. Revista Brasileira de Zootecnia, v.35, n.3, p.1245-1250, 2006 (supl.).

ABREU, U.G.P.; GOMES, E.G.; LOPES, P.S. et al. Avaliação sistêmica da introdução de tecnologias na pecuária de gado de corte do Pantanal por meio de modelos de análise envoltória de dados (DEA). Revista Brasileira de Zootecnia, v.37, n.11, p.2069-2076, 2008.

ALMEIDA, R. Consumo e eficiência alimentar de bovinos em crescimento. 181f. 2005. Tese (Doutorado-Agronomia) - Escola Superior de Agricultura "Luiz de Queiroz”/Universidade Federal de São Paulo, Piracicaba.

ANUALPEC 2010. Anuário da pecuária brasileira. São Paulo: Instituto FNP, 2010. 360p.

ARCHER J.A.; RICHARDSON E.C.; HERD R.M. et al. Potential for selection to improve feed efficiency of beef cattle: a review. Australian Journal of Agricultural Research, v.50, n.2, p.147-162, 1999.

BARROS, G.S.C.; ZEN, S.; BACCHI, M.R.P. et al. Economia da pecuária de corte na região norte do Brasil. Piracicaba: Centro de Estudos Avançados em Economia Aplicada, 2002. $75 p$.

BARROS, N.N.; VASCONCELOS, V.R.; WANDER, A.E. et al. Eficiência bioeconômica de cordeiros F1 Dorper x Santa Inês para produção de carne. Pesquisa Agropecuária Brasileira, v.40, n.8, p.825-831, 2005.

CARVALHO, T.B.; FERREIRA, P.C.; DE ZEN, S. Competitividade da pecuária de corte do Estado de São Paulo vs Mato Grosso do Sul e Mato Grosso. In: CONGRESSO DA SOCIEDADE BRASILEIRA DE ECONOMIA, SOCIOLOGIA E ADMINISTRAÇÃO RURAL, 46., 2008, Rio Branco. Anais... Rio Branco, 2008. (CD-ROM).

CARVALHO, T.B.; FURLANETTO, LV.; DE ZEN, S. et al. Potencial da produtividade e rentabilidade da pecuária de corte no Mato Grosso. In: CONGRESSO DA SOCIEDADE BRASILEIRA DE ECONOMIA, SOCIOLOGIA E ADMINISTRAÇÃO RURAL, 48., 2010, Campo Grande. Anais... Campo Grande-MS, 2010. (CD-ROM).

CENTRO DE ESTUDOS AVANÇADOS EM ECONOMIA APLICADA - CEPEA. BOI/CEPEA: Valores recordes marcam pecuária de corte em 2010. Available at: <http:// www.cepea.esalq.usp.br/imprensa/?id_page=340\&id_art=3861> Accessed on: Jan. 31, 2011.

COSTA, F.P. Natureza econômica e impacto das pastagens no custo de produção da pecuária de corte. Campo Grande: Embrapa Gado de Corte, 2010. 2p. (Documentos, 181).

DIAS-FILHO, M.B. Produção de bovinos a pasto na fronteira agrícola. In: ZOOTEC 2010 - CONGRESSO BRASILEIRO DE 
ZOoteCniA, 20., 2010, Palmas. Anais... Palmas: Editora, 2010. p.131-145.

FERRAZ, J.B.S.; FELÍCIO, P.E.D. Production systems an example from Brazil. Meat Science, v.84, n.2, p.238-243, 2010.

FORESIGHT 2011. The future of food and farming. Available at: $<$ http://www.bis.gov.uk/assets/bispartners/foresight/docs/foodand-farming/11-546-future-of-food-and-farming-report.pdf> Accessed on: Jan. 31, 2011

GASQUES, J.G.; BASTOS, E.T.; VALDES, C. Preços da terra no Brasil. In: CONGRESSO DA SOCIEDADE BRASILEIRA DE ECONOMIA, SOCIOLOGIA E ADMINISTRAÇÃO RURAL, 46., 2008, Rio Branco. Anais... Rio Branco, 2008.

HOMMA, A.K.O. As questões emergentes e a agricultura na Amazônia In: CONGRESSO BRASILEIRO DE ECONOMIA E SOCIOLOGIA RURAL, 37., 1999, Foz do Iguaçu. Anais... [Foz do Iguaçu], [1999] (Compact disk).

INSTITUTO BRASILEIRO DE GEOGRAFIA E ESTATÍSTICA IBGE. [2006]. Pecuária - estabelecimento na agropecuária hectares. Rio de Janeiro. Available at: <http://www.sidra. ibge.gov.br/bda/pecua/default.asp? $\mathrm{z}=\mathrm{t} \& \mathrm{o}=23 \& \mathrm{i}=\mathrm{P}>$ Accessed on: Jan. 31, 2011.

MAIA, A.G.; ROMEIRO, A.R.; REYDON, B.P. Valoração de recursos ambientais: metodologias e recomendações. Campinas: IE.UNICAMP, 2004. p.1-39.

MOTTA, R.S. Manual para valoração econômica de recursos ambientais. Brasília: Ministério do Meio Ambiente, dos Recursos Hídricos e da Amazônica Legal, 1998. 218p.
NOGUEIRA, J.M., MEDEIROS, M.A., ARRUDA, F.S. Valoração econômica do meio ambiente: ciência ou empiricismo? Cadernos de Ciência \& Tecnologia, v.17, n.2, p.81-115, 2000.

RENNÓ, F.P.; PEREIRA, J.C.; LEITE, C.A.M. et al. Eficiência bioeconômica de vacas de diferentes níveis de produção de leite por lactação e estratégias de alimentação. Revista Brasileira de Zootecnia, v.37, n.4, p.765-772, 2008.

ORGANIZAÇÃO DAS NAÇÕES UNIDAS PARA AGRICULTURA E ALIMENTAÇÃO - FAO - How to feed the world in 2050 Available at: <http://www.fao.org/fileadmin/templates/wsfs/docs/ Issues_papers/HLEF2050_Global_Agriculture.pdf $>$. Accessed on: Jan. 31, 2011.

SACHS, R.C.C.; PINATTI, E. Análise do comportamento dos preços do boi gordo e do boi magro na pecuária de corte paulista, no período de 1995 a 2006. Revista de Economia e Agronegócio, v.5, n.3, p.329-351, 2007.

SANTOS, D.T.; CARVALHO, P.C.F.; NABINGER, C. et al. Eficiência bioeconômica da adubação de pastagem natural no sul do Brasil. Ciência Rural, v.38, n.2, p.437-444, 2008.

SEBRAE; SENAR; FARSUL. Diagnóstico da pecuária de corte no Estado do Rio Grande do Sul. Porto Alegre, 2005. 265p. (Relatório).

SOMWARU, A.; VALDES, C. [2004]. Brazil's beef production and its efficiency: A comparative study of scale economies. In: GTAP CONFERENCE ON GLOBAL ECONOMIC ANALYSIS, 70., 2004, Purdue. Available at: <https:// www.gtap.agecon.purdue.edu/resources/download/1860.pdf > Accessed on: Jan. 31, 2011. 